\title{
Characteristics of RP4 Tellurite-resistance Transposon Tn521
}

\author{
By DAVID E. BRADLEY, ${ }^{*}$ KANWAL K. GREWAL, ${ }^{1}$ DIANE E. TAYLOR ${ }^{2}$ \\ AND JEANETTE WHELAN ${ }^{1}$ \\ ${ }^{1}$ Faculty of Medicine, Memorial University of Newfoundland, St John's, Newfoundland A1B 3V6, \\ Canada \\ ${ }^{2}$ Department of Medical Microbiology and Infectious Diseases, University of Alberta, Edmonton, \\ Alberta T6G 2H7, Canada
}

(Received 16 November 1987; revised 22 February 1988)

\begin{abstract}
A restriction map of the tellurite-resistance ( $\mathrm{Te}^{\mathrm{r}}$ ) transposon $\mathrm{Tn} 521$ (parent plasmid RP4Ter) was prepared. Five sites from RP4Ter, including the EcoRI origin, were found in pIN25::Tn 521 . Tn 521 was inserted into a transferable $27.5 \mathrm{~kb}$ vector (pCU109) to make three different insertion mutants, in which the size of Tn 521 was measured accurately at $4.5 \mathrm{~kb}$. Unlike the $\mathrm{Te}^{\mathrm{r}}$ of IncHI2 plasmids, that of $\mathrm{Tn} 521$ in RP4Te $\mathrm{e}^{\mathrm{r}}$ was non-inducible. $\mathrm{Te}^{\mathrm{r}}$ was expressed in five widely differing bacterial species to which RP4Te ${ }^{r}$ was transferred from Escherichia coli. Electron micrographs of bacteria expressing the $\mathrm{Te}^{r}$ of RP4Ter, $\mathrm{H}$ complex plasmids, and chromosomal mutants, all revealed similar tellurium metal crystallites when the bacteria were grown in potassium tellurite medium. No other $\mathrm{Te}^{\mathrm{r}}$ determinants were found amongst 54 plasmids representing most incompatibility groups (excluding the $\mathrm{H}$ complex).
\end{abstract}

\section{INTRODUCTION}

Although low concentrations of tellurium are widespread in the environment (Schroeder et al., 1967), bacterial resistance to the element (in the form of tellurite) is comparatively rare, and generally plasmid-mediated (Summers \& Jacoby, 1977). In Escherichia coli, plasmids determining transferable tellurite resistance $\left(\mathrm{Te}^{r}\right)$ have been found to belong to incompatibility group $\mathrm{P} \alpha$ (not IncP $\beta$; Bradley, 1985), and some groups of the H complex (Taylor \& Summers, 1979). $\mathrm{Te}^{\mathrm{r}}$ is usually expressed constitutively, but in the case of IncP $\alpha$ plasmids it requires the activation of a silent gene by plating bacteria carrying the plasmids on medium containing a normally lethal level of tellurite; a Ter variant of RP4 was obtained in this way (RP4Ter ; Bradley, 1985). The $\mathrm{Te}^{r}$ determinant of RP4Ter is located in a transposable segment of DNA (Tn521) approximately $4.5 \mathrm{~kb}$ in size, its estimated location spanning the single EcoRI site of the plasmid (Bradley \& Taylor, 1987; Taylor \& Bradley, 1987). This paper defines these parameters more accurately by means of a detailed restriction map of Tn521. We have also investigated fundamental aspects of its biology including the level of $\mathrm{Te}^{\mathrm{r}}$ expressed, its expression in bacteria other than E. coli, and the structure of metallic tellurium produced by the resistance mechanism. These results are compared with corresponding data for the $\mathrm{Te}^{\mathrm{r}}$ determinant of the IncHI2 plasmid pMER610 (Jobling \& Ritchie, 1987).

\section{METHODS}

Bacterial strains, bacteriophages and plasmids. E. coli $\mathrm{K} 12$ background strains (relevant markers only cited) were JE2571 ( $\mathrm{Leu}^{-} \mathrm{Thr}^{-} \mathrm{Str}^{r} \mathrm{Spc}^{\mathrm{s}} \mathrm{Pil}^{-} \mathrm{Fla}^{-}$) and J53 ( $\mathrm{Pro}^{-} \mathrm{Met}^{-} \mathrm{Str}^{\mathrm{s}} \mathrm{Spc}^{\mathrm{s}} \mathrm{Pil}^{+} \mathrm{Fla}^{+}$). Other bacterial species were Acinetobacter calcoaceticus C91 (Divers et al., 1985), Alcaligenes odorans AO (St John's General Hospital), Pseudomonas aeruginosa PAO1150.1 (Bradley, 1980a), Pseudomonas putida PpS388 (Fennewald et al., 1978) and Serratia marcescens SM13880 (ATCC 13880). Where appropriate, mutants resistant to nalidixic acid, rifampicin or spectinomycin (suffixes $-1,-2,-4$, respectively) were constructed. We tested 54 plasmids, which are not cited individually, for the generation of $\mathrm{Te}$; most were from the list of Jacob et al. (1977). Other plasmids used are 
Table 1. Plasmids used

\begin{tabular}{|c|c|c|c|}
\hline Plasmid & $\begin{array}{c}\text { Inc } \\
\text { group }\end{array}$ & $\begin{array}{l}\text { Resistance } \\
\text { markers* }\end{array}$ & Reference \\
\hline F & FI & Nil & Jacob et al. (1977) \\
\hline $\mathrm{F}:: \operatorname{Tn} 52 I$ & FI & $\mathrm{Te}$ & Bradley \& Taylor (1987) \\
\hline RP4 & $\mathbf{P}$ & Ap Km Tc & Jacob et al. (1977) \\
\hline RP4Ter & $\mathbf{P}$ & $\mathrm{Ap} \mathrm{Km} \mathrm{Tc} \mathrm{Te}$ & Bradley (1985) \\
\hline pIN25 & $\mathrm{T}$ & $\mathrm{Ap} \mathrm{Km}$ & Bradley \& Whelan (1985) \\
\hline pIN $25:: \operatorname{Tn} 521$ & $\mathrm{~T}$ & $\mathrm{Ap} \mathrm{Km} \mathrm{Te}$ & Bradley \& Taylor (1987) \\
\hline pCU109 & Nil & $\mathrm{Cm}$ & Thatte et al. (1985) \\
\hline pMN705 & Nil & $\mathrm{Te}$ & This paper \\
\hline pMN706 & Nil & $\mathrm{Cm} \mathrm{Te}$ & This paper \\
\hline pMN808 & Nil & $\mathrm{Cm} \mathrm{Te}$ & This paper \\
\hline
\end{tabular}

*Abbreviations: Ap, ampicillin; $\mathrm{Cm}$, chloramphenicol; $\mathrm{Km}$, kanamycin; $\mathrm{Tc}$, tetracycline; Te, tellurium as potassium tellurite.

recorded in Tables 1 and 2. Those in Table 2 are listed by Jacob et al. (1977) and Jacoby (1977) save for pMG1 10 (Wolfson et al., 1982) and pMUR162 (Datta \& Hughes, 1983). Phage PR4 (Stanisich, 1974) was used to check for the constitutive synthesis of $\mathrm{N}$ pili.

Media, antibiotics, culture methods, matings. These, including drug concentrations and cross-streak mating, were as described previously (Bradley, 1984, 1985; Bradley et al., 1981). Difco Nutrient Broth was used for induction experiments, and Brain Heart Infusion Broth or Agar (BBL) for routine purposes. Te ${ }^{r}$ was selected using potassium tellurite $\left(\mathrm{K}_{2} \mathrm{TeO}_{3}\right)$ at $5 \mu \mathrm{g} \mathrm{ml}^{-1}\left(=2 \times 10^{-5} \mathrm{M}-\mathrm{Te}\right)$ in Brain Heart Infusion agar. Mueller Hinton Broth (BBL) was used to determine minimum inhibitory concentrations of potassium tellurite (see below). Overnight plate matings were as described by Bradley et al. (1980) save that plates were incubated overnight instead of for $1 \mathrm{~h}$.

Determination of mutation frequencies for drug and tellurite resistances. The chromosomal mutation frequencies for $\mathrm{Str}^{r}, \mathrm{Spc}^{r}$ and $\mathrm{Te}^{r}$, and the $\mathrm{Te}^{r}$ generation frequency of plasmid RP4 to RP4Ter , were estimated by growing a shake culture of the strain under test to $\mathrm{OD}_{620} 1 \cdot 0$, then spreading $110 \mathrm{ml}$ of the culture on $15 \mathrm{~cm}$ diameter nutrient plates containing the agent under test. After $1-2 \mathrm{~d}$ incubation at $37^{\circ} \mathrm{C}$, only one or two colonies were usually obtained, so the values given are approximate.

Transpositions. The general approaches advocated by Foster (1984) and Bennett (1984) were used. Detection of transpositions of $\mathrm{Tn} 521$ to other replicons has been found difficult due to an apparent very low transposition frequency (not measured) combined with the abiliity of $E$. coli to form colonies with transient $\mathrm{Te}^{\mathrm{r}}$. Tn $52 l$ selection was therefore by means of derepressed $\mathrm{Te}^{\mathrm{r}}$ transfer (Bradley \& Taylor, 1987), using a transfer-derepressed vector such as pCU109 $(27.5 \mathrm{~kb})$. It carries the transfer operon of a wild-type IncN plasmid together with the chloramphenicol-resistance marker and multicopy charcteristics of pACYC184 (Thatte et al., 1985). A nontransferable varient of $\mathrm{F}:: \mathrm{Tn} 521$ was the best donor plasmid since it had no potentially transposable ampicillin resistance, although it did contain Tn 1000 (no resistance or other markers; Guyer, 1978). A strain containing both the transposon donor plasmid and the target plasmid was constructed, occasionally being stored on Dorset egg medium (Bennett, 1984). This strain was crossed with JE2571-1 ( $\mathrm{Nal}^{\mathrm{r}}$ ) by overnight plate mating (Bradley et al., 1980). A large loopful (about $10^{10}$ cells) from this mating was spread on selective agar (nalidixic acid/tellurite). Antiserum to donor conjugative pili was also added to broth mating mixtures (equal volumes) to prevent the transfer of $\mathrm{Tra}^{+}$revertant plasmids. Up to 500 transconjugants were cross-streak mated with JE2571-2 (rifampicin/tellurite selection) without purification. Transconjugants of strains giving derepressed transfer of Ter were purified and then screened for plasmid content by agarose gel electrophoresis (see below). In a first screening, clones giving clear DNA bands after linearizing with $E c o$ RI (unique site) were selected. We chose plasmids which were not unresolved cointegrates (with $\mathrm{F}:: \mathrm{Tn} 521$ ). Further selection was based on restriction patterns with other enzymes. It proved extremely difficult to obtain cells containing pCU109:: Tn521 alone without copies of either pCU109:: Tn 1000.

Preparation of DNA and restriction enzyme analysis. Plasmid DNA was prepared as described by Taylor \& Brose (1985) and Whiteley \& Taylor (1983), or by a modification of the method of Birnboim \& Doly (1979). Restriction enzymes were used according to the manufacturers' recommendations (BRL and United States Biochemical Corporation). The size standard was phage $\lambda$ DNA digested with various enzymes. Gel illustrations have not been included as experimental evidence, but reviewers have seen key photographs, which are identified by '(see Methods)'.

$T e^{r}$ inducibility tests. The experimental approach was that of Silver et al. (1981). We used a long exposure of strains carrying RP4 or RP4Ter to sublethal molarities of tellurium (see Results) since short-term exposure had no 


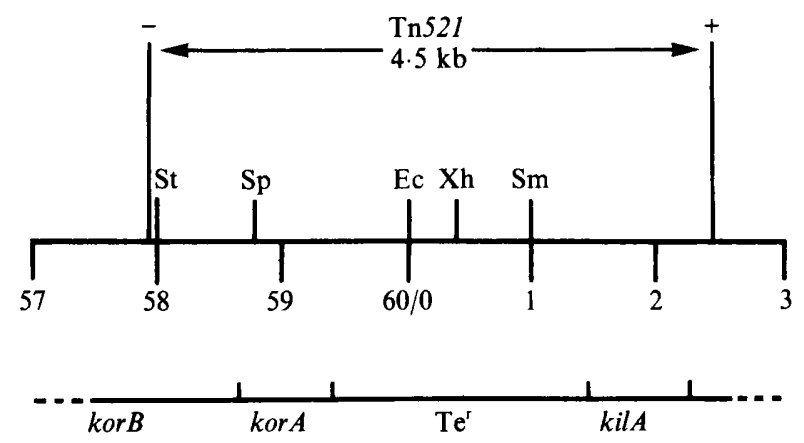

Fig. 1. Restriction map of $\mathrm{Tn} 521$ with reference to the region where it is located in the parent plasmid RP4Ter (RP4 mutant plasmid expressing $\mathrm{Te}^{\mathrm{r}}$; see Bradley, 1985). The map is based on a $60 \mathrm{~kb}$ RP4 replicon (Lanka et al., 1983), restriction sites, etc., being extrapolated from the $56.4 \mathrm{~kb}$ size used elsewhere (Figurski et al., 1982; Taylor \& Bradley, 1987). + and - identify the transposon orientations in Fig. 2. Abbreviations for restriction enzymes: Ec, EcoRI; Sm, SmaI; Sp, SphI; St, SstII; Xh, XhoI. This array is quite different from that found by Jobling \& Ritchie (1987) for the $\mathrm{Te}$ determinant of the IncHI2 plasmid pMER610 (BglI, BgIII, PstI, BamHI, HindIII, SalI, EcoRI).

effect. Attempted induction was by static overnight growth, followed by $10: 1$ dilution and $7 \mathrm{~h}$ shaking, then a repeat overnight static culture, all in potassium tellurite medium.

Determination of minimum inhibitory concentration (MIC) of potassium tellurite. The method of Waterworth (1978) was based on visually observing the end-point of bacterial growth in Mueller Hinton Broth containing stepwise dilutions of potassium tellurite. The lowest potassium tellurite concentration without bacterial growth was recorded as the MIC.

Electron microscopy. Bacteria were grown overnight in Brain Heart Infusion Broth containing $50 \mu \mathrm{g}$ potassium tellurite $\mathrm{ml}^{-1}$, equivalent to $10 \mu \mathrm{g} \mathrm{Te}$ metal $\mathrm{ml}^{-1}$. They were mounted on electron microscope specimen support grids and negatively stained by standard methods.

\section{RESULTS}

\section{Restriction map of Tn521}

The size of the RP4 replicon used was $60 \mathrm{~kb}$ (Lanka et al., 1983). We employed two approaches to map Tn521 and locate it accurately on its RP4Ter parent plasmid. In the first, we determined which RP4Te ${ }^{r}$ restriction sites in the vicinity of the Ter determinant (SmaI, XhoI, EcoRI, SphI, SstII; see Taylor \& Bradley, 1987 and Fig. 1) were acquired by the $132 \mathrm{~kb}$ IncT plasmid pIN25 after transposition of Tn521 to form pIN25:: Tn 521 . We found that all had been added to the pIN25 replicon. An additional $3.2 \mathrm{~kb} E c o$ RI fragment (unique to the recombinant) was cut in EcoRI + SstII double digests to give two fragments of $1.96 \mathrm{~kb}$ and $1.24 \mathrm{~kb}$ (see Methods), demonstrating the acquisition of an SstII site; this result located one end of the transposon (see below).

In the second approach we used $\mathrm{F}:: \mathrm{Tn} 521$ as donor plasmid to obtain three $\mathrm{Tn} 521$ insertions into pCU109 at different loci. These were used to give an accurate size measurement and to locate the transposon ends. The first plasmid (pMN705) was found in the course of screening for loss of the pCU109 $\mathrm{Cm}^{\mathrm{r}}$ marker caused by transposon insertion. It contained $\mathrm{Tn} 1000$ rather than Tn521 in the $\mathrm{Cm}^{\mathrm{r}}$ determinant, although both transposons were carried by this plasmid. The exact location of Tn 1000 was found by HindIII digestion, which gave fragments of 2.5, 2.7, 4.5 and approximately $30 \mathrm{~kb}$ (Fig. $2 a$; see Methods). The transferability of the $\mathrm{Te}^{\mathrm{r}}$ of pMN705 remained derepressed, indicating Tn521 insertion outside the transfer operon. An XhoI digest giving fragments of $2 \cdot 7,3 \cdot 1,4 \cdot 5$ and about $28 \mathrm{~kb}$ (see Methods) located Tn521 and gave a size estimate of $4.5-6.0 \mathrm{~kb}$ (Fig. $2 a$ ). An extra SstII site was acquired in addition to that present in $\mathrm{Tn} 1000$. Its location at one end of $\mathrm{Tn} 521$ was indicated by restriction enzyme digests of two other pCU109::Tn521 recombinants, pMN706 and pMN808, both lacking Tn1000. They no longer determined transferability in spite of being selected for it ; the apparent $\mathrm{Tra}^{+}$phenotype 


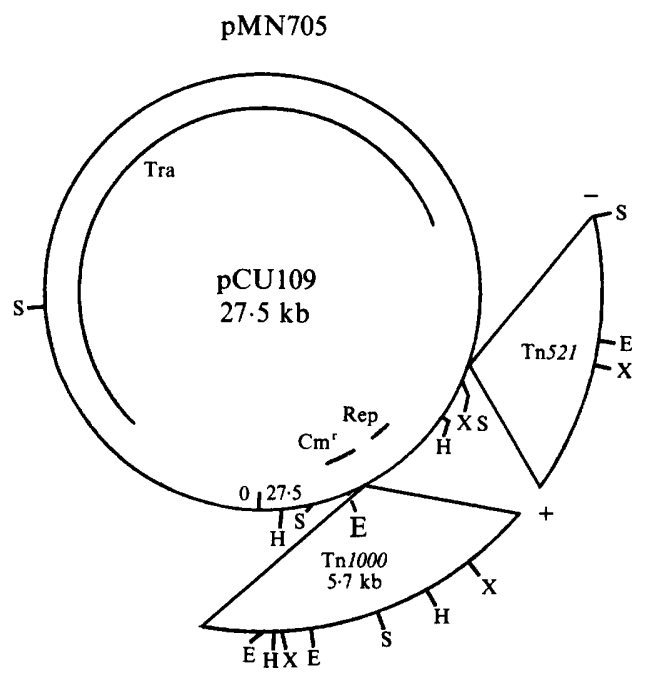

(a)

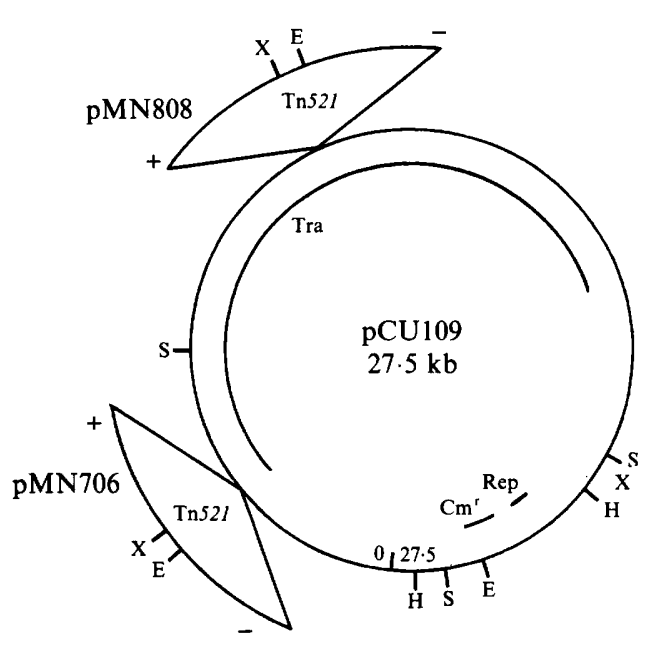

(b)

Fig. 2. (a) pMN705 showing insertions of $\operatorname{Tn} 1000$ and $\operatorname{Tn} 521$. (b) Locations of $\operatorname{Tn} 521$ insertions in pMN706 and pMN808. + and - define the orientation of Tn52l with reference to Fig. 1. Abbreviations: E, EcoRI; H, HindIII; S, SstII; X, XhoI; $\mathrm{Cm}^{\mathrm{r}}$, chloramphenicol resistance; Rep, replication; Tra, transfer.

found during initial screening (Methods) was due to efficient mobilization of the plasmids by pCU109. Tn521 insertion into the transfer operon of pCU109 permitted its location using SstII, $E c o$ RI and $X h o I$ digests (Fig. $2 b$ ). With SstII, pMN706 gave only three fragments, the same number as the vector. This showed that the SstII site acquired by pIN25::Tn 521 and pMN705 was absent (see below). Two of the three SstII fragments were the same size in pMN706 and the vector pCU109 $(15.5$ and $4.1 \mathrm{~kb})$, but the third fragment was $12.4 \mathrm{~kb}$ in pMN706 and $7.9 \mathrm{~kb}$ in pCU109 (see Methods). This gave an accurate size of $4.5 \mathrm{~kb}$ for Tn521, the same as the original estimate (Bradley \& Taylor, 1987). pMN808 also had only three SstII sites, Tn521 inserting into a $15.6 \mathrm{~kb}$ fragment of pCU109 increasing its size to about $20 \mathrm{~kb}$ (see Methods). An EcoRI digest of pMN808 gave a $16.0 \mathrm{~kb}$ doublet, which clearly located the $\mathrm{Tn} 521$ insertion point in a different position from that in pMN706 (Fig. $2 b$ ).

The variability in the appearance on different recipient plasmids of the additional SstII site which we have located at the 'minus' end of Tn521 (Fig. 1) may be explained by the transposon having only one constant end (Fig. 1, +). The variable end could have two possible end-points (i.e. direct inverted repeat sequences). Alternatively the sequence at the $\operatorname{Tn} 521$ terminus together with the sequence at the insertion site on the recipient plasmid may have generated an SstII site present on neither element. However, it seems improbable that such a site would be generated at random while another $S s t$ II site is known to be present close to one end of the transposable region of the parent plasmid RP4Ter (Taylor \& Bradley, 1987). Furthermore, identical sequences would have to be recognized at the insertion sites in the two very different recipient plasmids pIN25 and pCU109. While the only way to settle the question unequivocally would be to determine the relevant sequences, either explanation pinpoints the transposon end at or near the $S s t I I$ site. The 'plus' end of Tn 521 was defined by the $4.5 \mathrm{~kb}$ size measurement; the nearest RP4Ter restriction site to the $S m a \mathrm{I}$ site at $1 \mathrm{~kb}$ was a $P$ st I site $5 \mathrm{~kb}$ away in a clockwise direction (see Lanka et al., 1983). While these results are not conclusive, they suggested that both kilA and korA (Figurski et al., 1982; Bechhofer et al., 1986) were included in Tn521. The restriction sites located in the $\mathrm{Te}^{\mathrm{r}}$ determinant of the IncHI2 plasmid pMER610 by Jobling \& Ritchie (1987) are different from those in Tn521 (see Fig. 1 legend). 


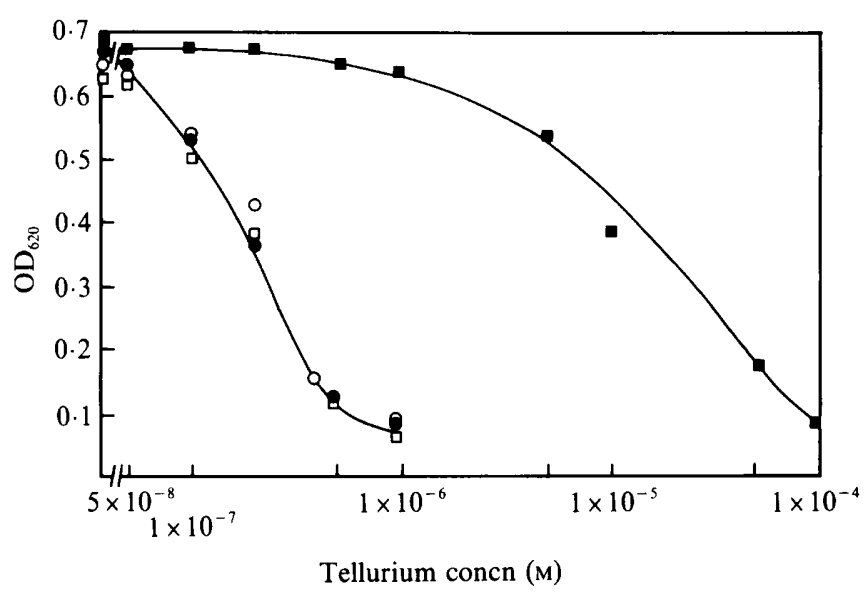

Fig. 3. Determination of sublethal Te concentrations. Shake cultures of the strains were grown in different concentrations of potassium tellurite in Difco Nutrient Broth until the control culture without Te had reached $\mathrm{OD}_{620} 0.68(5 \mathrm{~h})$. The $\mathrm{OD}_{620}$ values of the other cultures were measured and plotted against Te concentration. $O$, JE2571;, JE2571(RP4); $\square$, JE2571(RP4) after overnight growth in broth containing $5 \times 10^{-8} \mathrm{M} \mathrm{Te} ; \mathbf{\square}, \mathrm{JE} 2571(\mathrm{RP4Te})$.

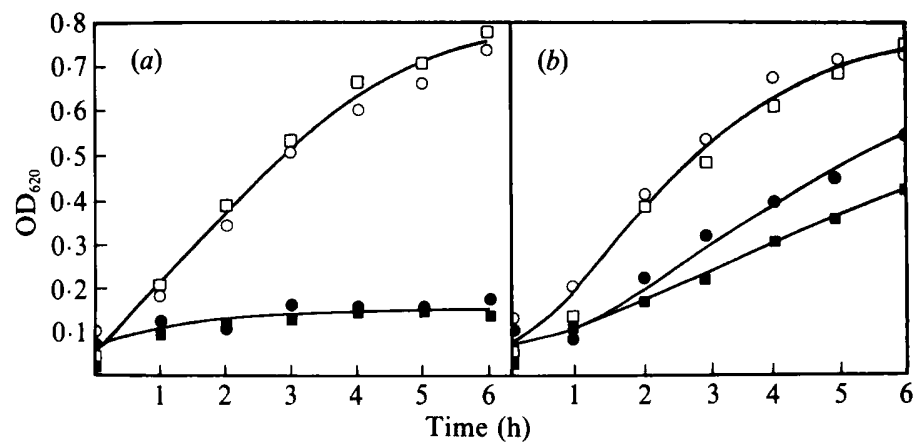

Fig. 4. (a) Growth in $1 \times 10^{-6} \mathrm{M}$-Te medium of JE2571(RP4) after growth in $5 \times 10^{-8} \mathrm{M}$-Te medium (see Methods). JE2571(RP4) control: $O$, in plain broth; $O$, in Te broth. JE2571(RP4) previously grown in $5 \times 10^{-8} \mathrm{M}$-Te medium: $\square$, in plain broth; $\square$, in Te broth. (b) Growth in $1 \times 10^{-5} \mathrm{M}$-Te medium of JE2571(RP4Ter) after growth in $2 \times 10^{-7} \mathrm{M}$-Te medium. JE2571(RP4Ter) control: $O$, in plain broth; $O$, in Te broth. JE2571(RP4Ter) previously grown in $2 \times 10^{-7} \mathrm{M}$-Te medium : $\square$, in plain broth; $\mathbf{\square}$, in Te broth.

\section{Non-inducibility of $T e^{r}$ determinant of Tn521}

Jobling \& Ritchie (1987) demonstrated the inducibility of the $\mathrm{Te}^{\mathrm{r}}$ determinant of the IncHI2 plasmid pMER610, a high level of $\mathrm{Te}^{\mathrm{r}}$ appearing in the host bacterium after only $30 \mathrm{~min}$ exposure to a sublethal level of Te (see Silver et al., 1981). We tested E. coli JE2571(RP4Ter) but used a much longer exposure, since preliminary results with short-term exposure suggested noninducibility. The maximum sublethal molarities of Te for test strains were determined (Fig. 3): JE2571 and JE2571(RP4), $5 \times 10^{-8} \mathbf{M}$; JE2571(RP4Ter), $2 \times 10^{-7}$ M. JE2571(RP4Ter) was sensitive to $1 \times 10^{-4} \mathrm{M}$-Te (Fig. 3). To test the inducibility of the unexpressed $\mathrm{Te}^{\mathrm{r}}$ determinant of RP4, we measured the growth rate in $1 \times 10^{-6} \mathrm{M}$-Te medium of strain JE2571(RP4) that had been grown in $5 \times 10^{-8} \mathrm{M}$-Te through three subcultures over $24 \mathrm{~h}$ (see Methods). JE2571(RP4) exposed to a low level of potassium tellurite did not grow any faster than the control JE2571(RP4) (Fig. 4a). To test the inducibility of the $\mathrm{Te}^{\mathrm{r}}$ of RP4Ter, we used a sublethal Te concentration of $2 \times 10^{-7} \mathrm{M}$ to induce resistance (Fig. 3), and $1 \times 10^{-5} \mathrm{M}$ for the challenge. The 
Table 2. MIC of potassium tellurite for various bacterial species with and without plasmids

\begin{tabular}{|c|c|c|c|c|}
\hline Species & Strain & Plasmid & $\begin{array}{l}\text { Inc } \\
\text { group }\end{array}$ & $\begin{array}{l}\text { MIC of potassium } \\
\text { tellurite }\left(\mu \mathrm{g} \mathrm{ml}^{-1}\right)\end{array}$ \\
\hline Escherichia coli & $\mathrm{JE} 2571-1 \mathrm{Te}^{\mathrm{r} *}$ & None & None & 325 \\
\hline \multirow[t]{11}{*}{ Escherichia coli } & JE2571 & None & None & 3 \\
\hline & & RP4 & $\mathrm{P}$ & 4 \\
\hline & & $\mathrm{RP}^{4} \mathrm{Te}^{\mathrm{r}}$ & $\mathbf{P}$ & 325 \\
\hline & & pIN25 & $\mathrm{T}$ & 4 \\
\hline & & pIN25::Tn521 & $\mathrm{T}$ & 275 \\
\hline & & $\mathrm{F}$ & FI & 4 \\
\hline & & $\mathrm{F}:: \operatorname{Tn} 521$ & FI & 300 \\
\hline & & R478 & HIl & 240 \\
\hline & & MIP233 & $\mathrm{HI} 3$ & 100 \\
\hline & & pMG110† & HII & 175 \\
\hline & & pMUR162 & None & 175 \\
\hline \multirow{2}{*}{ Serratia marcescens } & ATCC 13880 & None & None & 10 \\
\hline & & $R P 4 T e^{r}$ & $\mathrm{P}$ & 250 \\
\hline \multirow[t]{6}{*}{ Pseudomonas aeruginosa } & PAO1 150.1 & None & None & 75 \\
\hline & & RP4 & P-1 & 75 \\
\hline & & $\mathrm{RP}^{4} \mathrm{Te}^{\mathrm{r}}$ & P-1 & 300 \\
\hline & & CAM & $\mathrm{P}-2$ & 100 \\
\hline & & OCT & P-2 & 100 \\
\hline & & RPL11 & P-2 & 90 \\
\hline \multirow{2}{*}{ Pseudomonas putida } & PpS388 & None & None & 6 \\
\hline & & RP4Ter & P-1 & 375 \\
\hline \multirow{2}{*}{ Alcaligenes odorans } & Clinical & None & None & 30 \\
\hline & & $\mathrm{RP} 4 \mathrm{Te}^{\mathrm{r}}$ & $\mathbf{P}$ & 475 \\
\hline \multirow[t]{2}{*}{ Acinetobacter calcoaceticus } & C91 & None & None & 175 \\
\hline & & RP4Ter & $\mathbf{P}$ & 300 \\
\hline
\end{tabular}

growth rates of pre-exposed and control cultures were compared (Fig. $4 b$ ). Since the pre-exposed culture of JE2571(RP4Ter) did not grow as well as the control, it was concluded that neither the $\mathrm{Te}^{\mathrm{r}}$ of RP4 nor that of RP4Ter was inducible.

\section{Generation of Ter by E. coli K12 and plasmids}

We searched for a Tn521-like transposon in representative plasmids (usually three examples) of currently recognized incompatibility groups B, C(A), C, D, FI, FII, HI1, I1, I1 + B, I2, J, K, M, N, SI, SII, SIII, T, U, W, X and Z by screening for Ter generation (Bradley, 1985). Stable Ter derivatives were isolated from strains harbouring one plasmid from groups D (R687; Bradley, 1980 b), FII (R100), SII (R71; Coetzee et al., 1986) and W (R388), also R1343b and R40a (IncC). Since the $\mathrm{Te}^{r}$ in these mutants was not transferable, it was probably due to chromosomal mutation. This was tested by comparing the mutation frequencies for $\mathrm{Te}^{\mathrm{r}}, \mathrm{Str}^{\mathrm{r}}$ and $\mathrm{Spc}^{\mathrm{r}}$ for host strains: J53, $1.7 \times 10^{-9} \mathrm{Te}^{\mathrm{r}}$ mutations per cell, $9.3 \times 10^{-9} \mathrm{Str}^{\mathrm{r}}$ mutations per cell, and $1.0 \times 10^{-10} \mathrm{Spc}^{\mathrm{r}}$ mutations per cell; JE2571, <2.0 $\times 10^{-10} \mathrm{Te}^{\mathrm{r}}$ mutations per cell; JE2571-1, $5.0 \times 10^{-9} \mathrm{Te}^{r}$ mutations per cell. The difference between JE2571 and JE2571-1 presumably reflected clonal variation. JE2571(RP4) gave $1.7 \times 10^{-8} \mathrm{Te}^{r}$ mutations per cell [ $\mathrm{Te}^{\mathrm{r}}$ generation frequency; end product JE2571(RP4Ter)], which must be compared with JE2571 not JE2571-1.

\section{Expression of Th521 in different bacterial species}

Tn521 expression was demonstrated by comparing the MIC of potassium tellurite for bacterial species with and without the transposon in its broad-host-range parent plasmid RP4Ter. We found (i) that $\mathrm{Te}^{r}$ was expressed at a higher level than that of both $\mathrm{H}$ complex plasmids in E. coli, and IncP-2 plasmids in P. aeruginosa, and (ii) that it was expressed at high MIC levels in all the bacterial species tested, where it was transferable at derepressed frequencies (Table 2). The single exception was $P$. putida PpS388-2(RP4Ter), which gave a 
transfer frequency of only $2.3 \times 10^{-5}$ transconjugants per donor $\mathrm{h}^{-1}$ by plate mating. We also tested RP4Ter for determination of transferable resistance to the Te-related elements iodine, arsenic (arsenite and arsenate), antimony and selenium, but could find none (details not given).

\section{Electron microscopy of bacteria grown in tellurite medium}

Bacteria grown in or on potassium tellurite medium produce a black colour due to the reduction of potassium tellurite to tellurium metal (Tucker et al., 1962). We used electron microscopy of whole cells to ascertain if the form and location of the metal particles, not previously illustrated, was the same for all sources of the $\mathrm{Te}^{\mathrm{r}}$ determinant. $P$. aeruginosa PAO1150.1(RP4Ter) grown overnight in broth containing $50 \mu \mathrm{g}$ potassium tellurite $\mathrm{ml}^{-1}$ had dense crystallites in most of its cells (Fig. $5 a$ ). Sometimes these appeared to extend outside the cell (Fig. $5 a$, arrowed), but were surrounded by a single membrane (Fig. $5 b$ ), which we believe to be the outer membrane; reduction to Te metal presumably occurred at the inner membrane. E. coli JE2571-1 Te ${ }^{\mathrm{r}}$, JE2571(MIP233) and JE2571(RP4Ter), and $S$. marcescens SM13880(RP4Ter), all produced crystallites, varying in size from the relatively large ones of PAO1150.1(RP4Ter) to a finer form synthesized by SM13880(RP4Ter) (Fig. 5c).

\section{DISCUSSION}

The expression of a normally silent $\mathrm{Te}^{\mathrm{r}}$ determinant on plasmid RP4 was detected on potassium tellurite medium at $1.7 \times 10^{-8}$ mutations per cell, which was consistent with a point mutation in an as yet unspecified regulatory gene. This might conceivably be kor $A$, which is an autorepressor (Young et al., 1985) and is probably included in $\mathrm{Tn} 521$ (see below). The $\mathrm{Te}^{\mathrm{r}}$ system is not inducible, so $\mathrm{Te}^{r}$ expression might simply require a mutation in a repressor. Alternatively, the frequency of generation of $\mathrm{Te}^{\mathrm{r}}$ is consistent with the reversion of a previous mutation that inactivated the $\mathrm{Te}^{\mathrm{r}}$ structural gene.

Constitutive $\mathrm{Te}$ expression due to $\mathrm{Tn} 521$ appears possible in bacterial species included in the RP4 host range (Olsen \& Shipley, 1973), and in all cases studied here it involved the reduction of potassium tellurite to crystallites of metallic tellurium. The level of $\mathrm{Te}^{r}$ determined by $\mathrm{Tn} 521$ was much higher than that determined by $\mathrm{H}$ complex and other plasmids, and this might be considered to reflect a difference in $\mathrm{Te}^{\mathrm{r}}$ mechanisms. However, the metallic tellurium endproduct was the same in all cases and the variations in $\mathrm{Te}^{\mathrm{r}}$ levels probably reflected differences in the efficiencies of the same or similar metabolic pathways.

Our data suggest that both kilA and korA are present on Tn521. kilA, which has a lethal action on the host bacterium, is controlled by $\operatorname{kor} A$ together with $\operatorname{kor} B$ and $\operatorname{kor} E$ (Figurski et al., 1982; Young et al., 1985, 1987); korB and korE are outside Tn521. The possible inclusion of kilA and kor $A$ in $\mathrm{Tn} 521$ is based solely on restriction data and cannot be regarded as conclusive. However, if substantiated later, the important suggestion that plasmid-borne transposons could include genes determining essential replication functions will have to be examined. We have not yet attempted to detect kilA function determined by plasmids containing the transposon. Both kil $A$ and kor $A$ have been found in all other IncP $\alpha$ plasmids (Figurski et al., 1982; listed by Villarroel et al., 1983), most of which have been shown to generate transferable $\mathrm{Te}^{\mathrm{r}}$ (Bradley, 1985). We therefore consider it likely that some or all of these plasmids harbour Tn521-like transposons, although we have not been able to demonstrate this. This apparent lack of transposition could well have been due to a frequency too low to be detected. Indeed, Tn 521 was very difficult to transpose from RP4Ter to other plasmids and could not be transposed to the bacterial chromosome; a low transposition frequency or other limiting characteristic is not surprising, otherwise transposable $\mathrm{Te}^{\mathrm{r}}$ would be expected to occur in other plasmids; our tests, which are of a provisional nature, suggest that this is not the case.

The Ter determinants of RP4Ter (Tn521) and the IncHI2 plasmid pMER610 are distinct: (i) the restriction sites in Tn521 are different from those in the Ter determinant of pMER610 (see legend to Fig. 1), (ii) the $\mathrm{Te}^{r}$ of RP4Ter is constitutive whereas that of pMER610 is inducible, (iii) the level of $\mathrm{Te}^{r}$ expressed by RP4Ter is consistently higher than that expressed by $\mathrm{H}$ complex plasmids, (iv) the $\mathrm{Te}^{\mathrm{r}}$ of $\mathrm{H}$ complex plasmids does not appear to be transposable (D. E. Bradley $\&$ D. E. Taylor, unpublished results). However, the structural genes of the elements may or may 

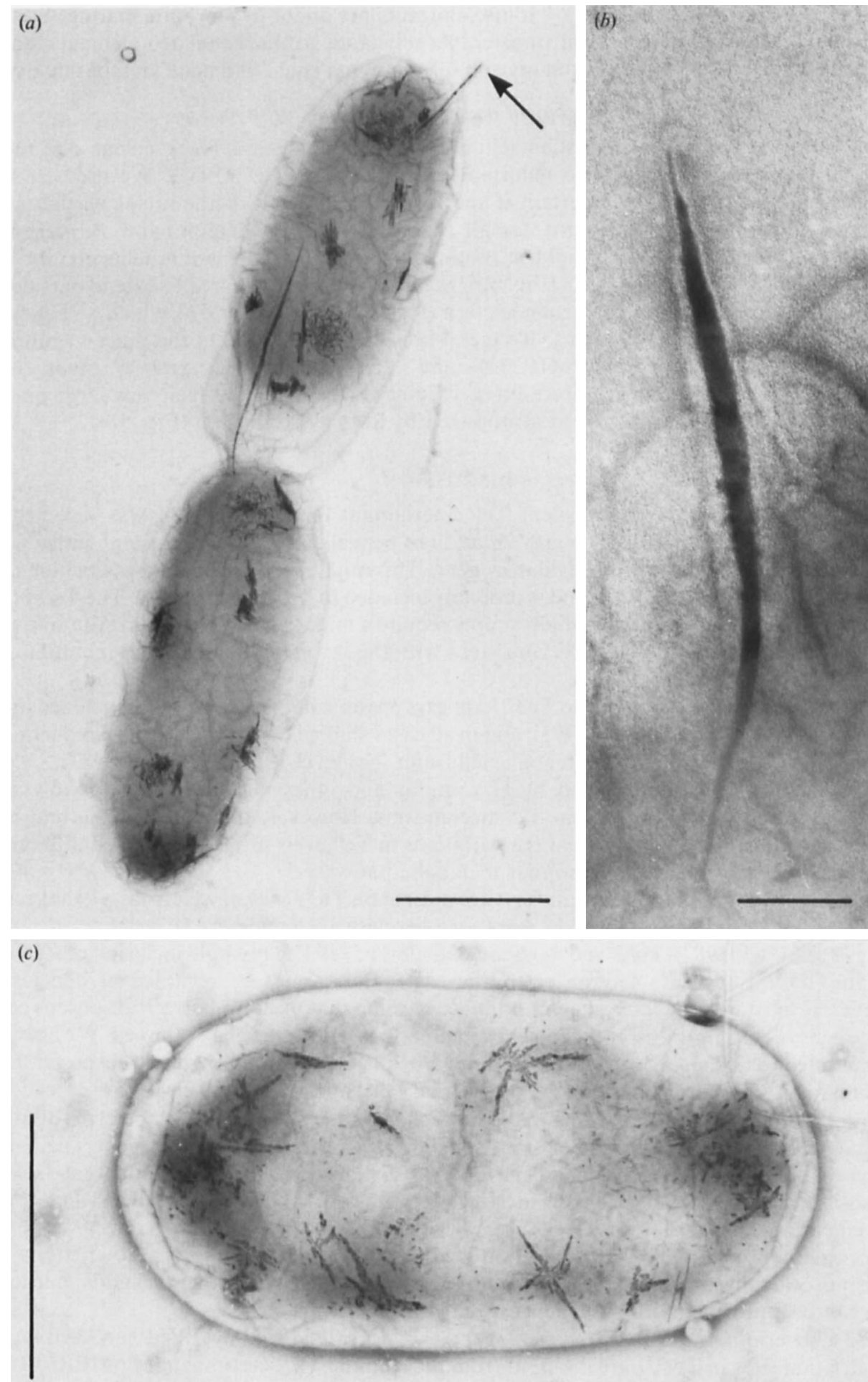

Fig. 5. Negatively stained cells grown in potassium tellurite medium. (a) Dividing cell of $P$. aeruginosa PAO1150.1(RP4Ter) with a tellurium crystallite (arrowed) extending out of the cell. Bar $1.0 \mu \mathrm{m}$. (b) detail of a similar crystallite. Bar $100 \mathrm{~nm}$. (c) S. marcescens SM13880(RP4Ter). Bar 1.0 $\mu \mathrm{m}$. 
not be related. We propose that the wild-type transposon in RP4, which does not express $\mathrm{Te}^{\mathrm{r}}$, be designated $\operatorname{Tn} 522$.

We are grateful to Elisa Brose, who isolated pIN25 DNA for restriction enzyme analysis. This work was supported by the Medical Research Council of Canada (grants MT5608 for D.E.B. and MT6200 for D.E.T.).

\section{REFERENCES}

BechHofer, D. H., Kornack, J. A., Firshein, W. \& FIGURSKI, D. H. (1986). Gene control in broad host range plasmid RK2: expression, polypeptide product, and multiple regulatory functions of $k o r B$. Proceedings of the National Academy of Sciences of the United States of America 83, 394-398.

BENNETT, P. M. (1984). Detection of transposable elements on plasmids. Methods in Microbiology 17, 227-231.

Birnboim, H. C. \& Doly, J. (1979). A rapid alkaline extraction procedure for screening recombinant plasmid DNA. Nucleic Acids Research 7, 1513-1523.

Bradley, D. E. (1980a). A function of Pseudomonas aeruginosa polar pili: twitching motility. Canadian Journal of Microbiology 26, 146-154.

BRADLEY, D. E. (1980b). Morphological and serological characteristics of conjugative pili. Plasmid 4, 155-169.

BRADLEY, D. E. (1984). Characteristics and function of thick and thin conjugative pili determined by transfer-derepressed plasmids of incompatibility groups $\mathrm{I}_{1}, \mathrm{I}_{2}, \mathrm{I}_{5}, \mathrm{~B}, \mathrm{~K}$ and $\mathrm{Z}$. Journal of General Microbiology 130, 1489-1502.

BraDley, D. E. (1985). Detection of tellurite-resistance determinants in IncP plasmids. Journal of General Microbiology 131, 3135-3137.

Bradley, D. E. \& Whelan, J. (1985). Conjugation systems of IncT plasmids. Journal of General Microbiology 131, 2665-2671.

BRADLEY, D. E. \& TAYLOR, D. E. (1987). Transposition from RP4 to other replicons of a tellurite-resistance determinant not normally expressed by IncP $\alpha$ plasmids. FEMS Microbiology Letters 41, 237-240.

Bradley, D. E., Taylor, D. E. \& Cohen, D. R. (1980). Specification of surface mating systems among conjugative drug resistance plasmids in Escherichia coli K-12. Journal of Bacteriology 143, 1466-1470.

Bradley, D. E., Coetzee, J. N., Bothma, T. \& Hedges, R. W. (1981). Phage t: a group T plasmiddependent bacteriophage. Journal of General Microbiology 126, 397-403.

Coetzee, J. N., Bradley, D. E., Hedges, R. W., Hughes, V. M., MCConNell, M. M., Du ToIT, L. \& TWEeHUYSEN, M. (1986). Bacteriophages $\mathrm{F}_{0}$ lac $h$, SR, SF: phages which adsorb to pili encoded by plasmids of the new S-complex. Journal of General Microbiology 132, 2907-2917.

Datta, N. \& Hughes, V. M. (1983). Plasmids of the same Inc groups in enterobacteria before and after the medical use of antibiotics. Nature, London 306, 616-617.

Divers, M., Craven, P. L. \& Vivian, A. (1985). Molecular analysis of an antibiotic resistance plasmid, pAV5, and its derivative plasmids in Actinetobacter calcoaceticus. Journal of General Microbiology 131, 3367-3374.
Fennewald, M. W., Prevatt, W., Meyer, R. \& SHAPIRO, J. (1978). Isolation of IncP-2 plasmid DNA from Psuedomonas aeruginosa. Plasmid 1, 164-173.

Figurski, D. H., Pohlman, R. F., BechHofer, D. H., Prince, A. S. \& Kelton, C. A. (1982). Broad host range plasmid RK2 encodes multiple kil genes potentially lethal to Escherichia coli host cells. Proceedings of the National Academy of the United States of America 79, 1935-1939.

FOSTER, T. J. (1984). Analysis of plasmids with transposons. Methods in Microbiology 17, 197-226.

GUYER, M. S. (1978). The gamma delta sequence of $F$ is an insertion sequence. Journal of Molecular Biology 126, 347-365.

Jacob, A. E., Shapiro, J. A., Yamamoto, L., Smith, D. I., CoHEN, S. N. \& BerG, D. (1977). Plasmids studied in Escherichia coli and other enteric bacteria. In DNA Insertion Elements, Plasmids and Episomes, pp. 607-638. Edited by A. I. Bukhari, J. A. Shapiro \& S. L. Adhya. Cold Spring Harbor Laboratory.

JACOBY, G. A. (1977). Classification of plasmids in Pseudomones aeruginosa. In Microbiology - 1977, pp. 119-126. Edited by D. Schlessinger, Washington, DC: American Society for Microbiology.

Jobling, M. G. \& Ritchie, D. A. (1987). Genetic and physical analysis of plasmid genes expressing inducible resistance of tellurite in Escherichia coli. Molecular and General Genetics 208, 288-293.

LANKA, E., LURZ, R. \& FURSTE, J. P. (1983). Molecular cloning and mapping of $S p h$ I restriction fragments of plasmid RP4. Plasmid 10, 303-307.

Olsen, R. H. \& SHIPLEY, P. (1973). Host range and properties of the Pseudomonas R factor R1822. Journal of Bacteriology 113, 772-780.

Schroeder, H. A., Buckman, J. \& Balassa, J. J. (1967). Abnormal trace elements in man: tellurium. Journal of Chronic Diseases 20, 1147-1161.

Silver, S., Budd, K., Leahy, K. M., ShaW, W. V., Hammond, D., Novick, R. P., Willsky, G. R., Malamy, M. H. \& Rosenberg, H. (1981). Inducible plasmid-determined resistance to arsenate, arsenite, and antimony(III) in Escherichia coli and Staphylococcus aureus. Journal of Bacteriology 146, 983-996.

STANISICH, V.A. (1974). The properties and host range of the male-specific bacteriophages of Pseudomonas aeruginosa. Journal of General Microbiology 84, 332-342.

Summers, A. O. \& JACOBY, G. A. (1977). Plasmiddetermined resistance to tellurium compounds. Journal of Bacteriology 129, 276-281.

TAYLOR, D. E. \& BRADLEY, D. E. (1987). Location on RP4 of a tellurite resistance determinant not normally expressed by IncP $\alpha$ plasmids. Antimicrobial Agents and Chemotherapy 31, 823-825.

TAYloR, D. E. \& BRose, E. C. (1985). Restriction endonuclease mapping of R27 (TP117), an incompatibility group HI subgroup 1 plasmid from Salmonella typhimurium. Plasmid 13, 75-77. 
TaYlor, D. E. \& Summers, A. O. (1979). Association of tellurium resistance and bacteriophage inhibition conferred by R plasmids. Journal of Bacteriology 137, $1430-1433$.

Thatte, V., Bradley, D. E. \& IYer, V. N. (1985). N conjugative transfer system of plasmid pCU1. Journal of Bacteriology 163, 1229-1236.

TuCKer, F. L., Walper. J. F., Appleman, M. D. \& DONOHUE, J. (1962). Complete reduction of tellurite to pure tellurium metal by microorganisms. Journal of Bacteriology 83, 1313-1314.

Villarroel, R., Hedges, R. W., Maenhaut, R. Leemans, J., ENgler, G., Van Montagu, M. \& Schell, J. (1983). Heteroduplex analysis of $P$ plasmid evolution: the role of insertion and deletion of transposable elements. Molecular and General Genetics 189, 390-399.

WATERWORTH, P. M. (1978). Quantatitive methods for bacterial sensitivity testing. In Laboratory Methods in Antimicrobial Therapy, pp. $30-40$. Edited by D. S. Reeves, I. Phillips, J. D. Williams \& R. Wise. Edinburgh: Churchill Livingstone.
WhITELEY, M. \& TAYLOR, D. E. (1983). Identification of DNA homologies among $\mathrm{H}$ incompatibility group plasmids by restriction enzyme digestion and Southern transfer hybridization. Antimicrobial Agents and Chemotherapy 24, 194-220.

Wolfson, J. S., Hooper, D. C., Swartz, M. N. \& McHugh, G. L. (1982). Antagonism of the B subunit of DNA gyrase eliminates plasmids pBR322 and pMG110 from Escherichia coli. Journal of Bacteriology 152, 338-344.

Young, C., Prince, A. S. \& Figurski, D. H. (1985). kor $A$ function of promiscuous plasmid $\mathrm{RK} 2$ : an autorepressor that inhibits expression of host-lethal gene kilA and replication gene $\operatorname{tr} f A$. Proceedings of the National Academy of Sciences of the United States of America 82, 7374-7378.

Young, C., Burlage, R. S. \& Figurski, D. H. (1987). Control of the kilA gene of the broad-host-range plasmid RK2: involvement of $\operatorname{kor} A, \operatorname{kor} B$, and a new gene, korE. Journal of Bacteriology 169, 1315-1320. 